\title{
The design of high-temperature thermal conductivity measurements apparatus for thin sample size
}

\author{
Syamsul Hadi ${ }^{1, *}$, Fama Aqiftiar Falah $^{1}$, Agus Kurniawan $^{2}$, and Suyitno ${ }^{1}$ \\ ${ }^{1}$ Graduate School of Mechanical Engineering Department, SebelasMaret University, Surakarta, Indonesia \\ ${ }^{2}$ Industrial Machine Engineering Department Polytechnic ATMI, Surakarta, Central Java, Indonesia
}

\begin{abstract}
This study presents the designing, constructing and validating processes of thermal conductivity apparatus using steady-state heat-transfer techniques with the capability of testing a material at high temperatures. This design is an improvement from ASTM D5470 standard where meter-bars with the equal cross-sectional area were used to extrapolate surface temperature and measure heat transfer across a sample. There were two meter-bars in apparatus where each was placed three thermocouples. This Apparatus using a heater with a power of 1,000 watts, and cooling water to stable condition. The pressure applied was 3.4 $\mathrm{MPa}$ at the cross-sectional area of $113.09 \mathrm{~mm} 2$ meter-bar and thermal grease to minimized interfacial thermal contact resistance. To determine the performance, the validating process proceeded by comparing the results with thermal conductivity obtained by THB 500 made by LINSEIS. The tests showed the thermal conductivity of the stainless steel and bronze are $15.28 \mathrm{Wm}-1 \mathrm{~K}-1$ and $38.01 \mathrm{Wm}-1 \mathrm{~K}-1$ with a difference of test apparatus THB 500 are $-2.55 \%$ and $2.49 \%$. Furthermore, this apparatus has the capability to measure the thermal conductivity of the material to a temperature of $400{ }^{\circ} \mathrm{C}$ where the results for the thermal conductivity of stainless steel is $19.21 \mathrm{Wm}-1 \mathrm{~K}-1$ and the difference was $7.93 \%$.
\end{abstract}

\section{Introduction}

Thermal conductivity is one of the important properties of the material and commonly is depend on the temperature especially in high-temperature condition [1]. The differences of thermal conductivity usually could be ignored and be measured based on the average temperature because the analysis will be complicated if the differences of temperature are involved in the analysis [2]. However, for certain materials particularly for thermoelectric material, the differences of thermal conductivity should not be ignored because thermoelectric operates at high temperature and the Seebeck number as the main parameter of its performance depends on thermal conductivity value [3]. Based on these facts, measurements of thermal conductivity in high temperature need special apparatus in order to obtain an accurate result.

Several methods for measuring thermal conductivity have already proposed such as steady state method using guarded hot plate (GHP) that it shows accuracy about $3 \%$ in deviation standard [4] and guarded cut-bar technique which measured thermal conductivity for the stainless steel 304 (SS304) was $19.17 \mathrm{Wm}^{-1} \mathrm{~K}^{-1}$ [5]. Another research using one dimension conduction steady state method and thermal jacket as a protector to minimize heat loss to the ambient was already reported [6]. Other efforts were proposed in collecting, monitoring, and processing data using acquisition Analog to Digital Converter (ADC) Advantech (USM-
4718) to the computer [7] and microcontroller ATMEGA16 [8]. All previous efforts are focused on improving new method in order to obtain more accurate measuring apparatus.

In the steady state method for the big samples thermocouples were bored in samples, but for the small samples, this method was not available. A commercial method of measuring thermal conductivity for thin samples usually is a transient method of laser flash diffusivity technique, but this method needs additional test in measuring process. Also, this method has a limitation in high thermal conductivity material and high-temperature measurements [9]. Other proposed thermal conductivity measurements have proposed using point probe method [10] and stamp sensor method [11, $12,13]$ that has the capability in in-situ measurements, but this method also has a limitation in high-temperature measurements. The common method in high-temperature thermal conductivity measurements is axial heat flow based on the standard of ASTM E1225-99 [14] which use a bored thermocouple in the specimen $[15,16]$. Unfortunately, the last method could not measure for a thermoelectric method which usually thins form and fragile in the machining process.

In this research thermal conductivity measurements, apparatus will be designed and manufactured using axial heat flow steady-state method for thin materials without a boring process to attach thermocouples and capable in various diameter samples. The validity of this apparatus was measured using Stainless Steel and Bronze materials

\footnotetext{
* Corresponding author: syamsulhadi@ft.uns.ac.id
} 
using ADAM 4018 as data acquisition. Further, the apparatus will be used to measure the thermal conductivity of thermoelectric semiconductor sample until the temperature of $400^{\circ} \mathrm{C}$.

\section{Research Method}

For the first design of thermal conductivity, measurements apparatus was built by using Solidworks computer simulations program. Several designs and applied materials are applied in order to obtain the best solution for one-dimensional thermal transfer, minimal power supply, minimal heat loss, ease of disassembly process, and steady state condition. The design of the apparatus in detail was shown in the Figures 1.

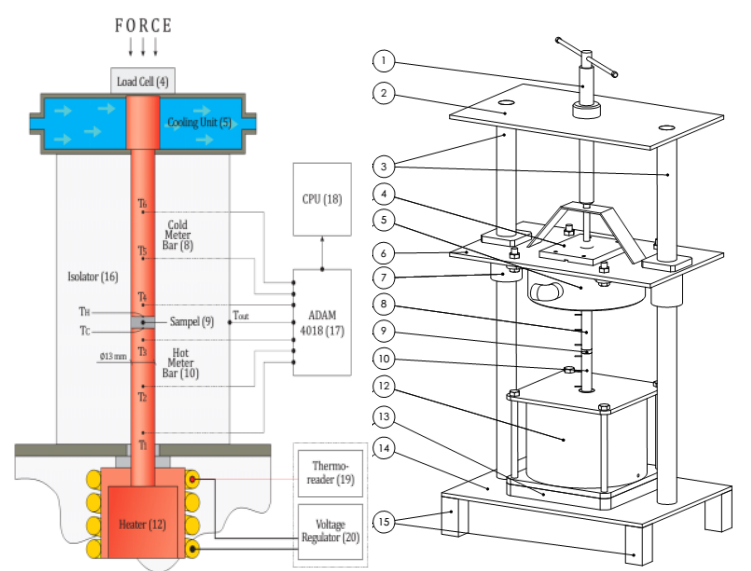

Fig. 1. Design of the apparatus

The frame of apparatus consists of a top base plate (2), middle base plate (6), bottom base plate (14) from mild steel material with a size of $300 \times 180 \times 5 \mathrm{~mm}$ and vertical rod (3) from stainless steel material with a height of 500 $\mathrm{mm}$ and diameter of $20 \mathrm{~mm}$. In the top base plate, there is a lever (1) giving the pressure to the sample during measurements process. The lever press the load cell (4) then the load cell continuing to the middle base plate which has the capability to move in up and down movement using sliding bearing linear (7) with a vertical rod. In the lower part of the middle base plate, there is a cooling unit (5). The cooling cold meter bar (8) on the one side using water as a cooling medium which circulates by a pump stabilizing the flow rate of the water so the measurements process in the steady state condition. In the bottom of the base plate, a set heater (12) we put and there is an isolator (13) between them avoiding the temperature at the lower part of the base plate too high. This apparatus was designed to be an apparatus which able to measure the sample in high temperature, so the heater element as the heating source of hot meter bar (10) was applied and placed on the lower side apparatus and controlled by a voltage regulator (20). The temperature of the heater was controlled by thermo-reader (19) from box panel. In the space between cold meter bar and hot meter bar, the specimen (9) with a diameter of $13 \mathrm{~mm}$ was placed. In each meter bar, there are three thermocouples (11) reading the gradient of temperature from hot meter bar to cold meter bar. Meter bar and specimens were veiled by isolator (16) in order to keep the system in the adiabatic condition. K-type thermocouples were used, and collected data from thermocouples were read by Analog to Digital Converter Advantech ADAM 4018 (17) and were transferred to the computer (18). Furthermore, this apparatus was designed to measure the thermal conductivity of thin materials from 0.02 to $10 \mathrm{~mm}$ which not available in bored thermocouples process. Various samples with a different thermal conductivity of $15 \mathrm{Wm}^{-}$ ${ }^{1} \mathrm{~K}^{-1}-50 \mathrm{Wm}^{-1} \mathrm{~K}^{-1}$ and sizeable to be measured using this apparatus just only change the meter bar size.

\section{Results and Discussion}

The proposed thermal conductivity measurements apparatus are intended to measure thermoelectric materials which have middle conductivity in the range of $15 \mathrm{Wm}^{-1} \mathrm{~K}^{-1}$ to $50 \mathrm{Wm}^{-1} \mathrm{~K}^{-1}$ [17]. In the validation process materials of stainless steel with a thermal conductivity of $\sim 15-20$ [18] and bronze with a thermal conductivity of $\sim 50-59[2,19]$ in range temperature of $50-400^{\circ} \mathrm{C}$ which have thermal conductivity value between those values were applied. Before validation process both of thermal conductivity materials were measured by using THB 500 LINSEIS in ambient temperature to a definite type of metal.

Because the minimum temperature in the apparatus when the apparatus is work was $50^{\circ} \mathrm{C}$, several assumptions were used in order to define thermal conductivity of materials. Table 2 shows results of thermal conductivity measurements using test of THB 500 LINSEIS in ambient temperature.

Table 1. Thermal conductivities as results using THB 500 LINSEIS test

\begin{tabular}{|c|c|c|c|c|}
\hline \multirow{2}{*}{$\begin{array}{c}\text { Sample } \\
\text { Number }\end{array}$} & \multicolumn{2}{|c|}{ Stainless steel } & \multicolumn{2}{c|}{ Bronze } \\
\cline { 2 - 5 } & $\mathbf{k}\left(\mathbf{W m}^{-1} \mathbf{K}^{-1}\right)$ & $\mathbf{T}\left({ }^{\circ} \mathbf{C}\right)$ & $\mathbf{k}\left(\mathbf{W m}^{-1} \mathbf{K}^{-1}\right)$ & $\mathbf{T}\left({ }^{\circ} \mathbf{C}\right)$ \\
\hline 1 & $14.92 \pm 2 \%$ & 31.22 & $38.89 \pm 2 \%$ & 29.50 \\
\hline 2 & $14.92 \pm 2 \%$ & 31.16 & $38.12 \pm 2 \%$ & 29.40 \\
\hline 3 & $14.98 \pm 2 \%$ & 31.10 & $38.15 \pm 2 \%$ & 29.30 \\
\hline 4 & $14.78 \pm 2 \%$ & 31.07 & $36.41 \pm 2 \%$ & 29.40 \\
\hline 5 & $14.80 \pm 2 \%$ & 31.06 & $38.50 \pm 2 \%$ & 29.50 \\
\hline Mean & $14.88 \pm 2 \%$ & 31.12 & $38.01 \pm 2 \%$ & 29.42 \\
\hline
\end{tabular}

The validation process for Stainless Steel material in the first step has to check the type of Stainless Stell itself. From THB 500 LINSEIS apparatus test the thermal conductivity of Stainless Stell materials at $31.12^{\circ} \mathrm{C}$ was $14.88 \mathrm{Wm}^{-1} \mathrm{~K}^{-1}$. Then it is compared to other references thermal conductivity $[15,16,18]$ which shows thermal conductivity value of Stainless Steel 304 (SS304) was $14.99 \mathrm{Wm}^{-1} \mathrm{~K}^{-1}$ at temperature $31.12^{\circ} \mathrm{C}$ and difference about $0,73 \%$. THB 500 LINSEIS test apparatus has capability only at room temperature, so if the test is at $50^{\circ} \mathrm{C}$, from the different research thermal conductivity of stainless steel $304 \mathrm{~T}$ temperature of $50^{\circ} \mathrm{C}$ 
was $15.28 \mathrm{Wm}^{-1} \mathrm{~K}^{-1}$ [18]. The best-obtained data of thermal conductivity of 304 stainless steel comparing to the literature is $-0.64 \%$ by $5^{\text {th }}$ number test and the biggest difference is $-6.25 \%$ on $3^{\text {rd }}$, see Table 3 . Furthermore, from the Table 3, the apparatus demonstrates the proper testability of stainless steel with an average difference from the literature only by $-2.55 \%$ with a standard deviation is $0.33 \mathrm{Wm}-1 \mathrm{~K}-1$ or $2.09 \%$.

Table 2. The thermal conductivity of Stainless steel at $50^{\circ} \mathrm{C}$ $\left(k_{\mathrm{ref}}=15.28 \mathrm{Wm}^{-1} \mathrm{~K}^{-1}\right)$.

\begin{tabular}{|c|c|c|}
\hline $\begin{array}{c}\text { Sample } \\
\text { number }\end{array}$ & $\begin{array}{c}\boldsymbol{k} \\
\left(\mathbf{W m}^{-1} \mathbf{K}^{-1}\right)\end{array}$ & $\begin{array}{c}\text { Deviation } \\
(\%)\end{array}$ \\
\hline 1 & 15.55 & $-1.73 \%$ \\
\hline 2 & 15.64 & $-2.35 \%$ \\
\hline 3 & 16.24 & $-6.25 \%$ \\
\hline 4 & 15.55 & $-1.74 \%$ \\
\hline 5 & 15.39 & $-0.69 \%$ \\
\hline Mean & 15.67 & $-2.55 \%$ \\
\hline SD & \multicolumn{2}{|c|}{$\mathbf{0 . 3 3}$} \\
\hline
\end{tabular}

The thermal conductivity of commercial bronze of $38.01 \mathrm{Wm}^{-1} \mathrm{~K}^{-1}$ was measured at a temperature of $29.42^{\circ} \mathrm{C}$. From other literature the value of thermal conductivity of bronze was not changed until the temperature of $127^{\circ} \mathrm{C}[2,19]$, so the thermal conductivity of bronze at a temperature of $50^{\circ} \mathrm{C}$ can be assumed to be same as result of THB 500 LINSEIS test at a temperature of $29.42^{\circ} \mathrm{C}$.

Table 3. Thermal conductivities of commercial bronze at a temperature of $50^{\circ} \mathrm{C}\left(k_{\text {ref }}=38.01 \mathrm{Wm}^{-1} \mathrm{~K}^{-1}\right)$.

\begin{tabular}{|c|c|c|}
\hline $\begin{array}{c}\text { Sample } \\
\text { Number }\end{array}$ & $\begin{array}{c}\boldsymbol{k} \\
\left(\mathbf{W m}^{-\mathbf{1}} \mathbf{K}^{-\mathbf{1}}\right)\end{array}$ & $\begin{array}{c}\text { Deviation } \\
(\mathbf{\%})\end{array}$ \\
\hline 1 & 35.97 & $5.38 \%$ \\
\hline 2 & 38.94 & $-2.43 \%$ \\
\hline 3 & 36.34 & $4.40 \%$ \\
\hline 4 & 37.55 & $1.21 \%$ \\
\hline 5 & 36.54 & $3.88 \%$ \\
\hline Mean & 37.07 & $2.49 \%$ \\
\hline SD & \multicolumn{2}{|c|}{$\mathbf{1 . 2 0}$} \\
\hline
\end{tabular}

Table 4 shows results from five test of thermal conductivity of commercial bronze at a temperature of $50^{\circ} \mathrm{C}$ with the best result at fourth with the smallest difference only of $1.21 \%$ and the biggest difference of $5.38 \%$ at the first data. Deviation standard for all five data was $1.20 \mathrm{Wm}^{-1} \mathrm{~K}^{-1}$ or $3.23 \%$. From the previous validation, good results were shown for all materials at middle thermal conductivity $\left(15 \mathrm{Wm}^{-1} \mathrm{~K}^{-1}-50 \mathrm{Wm}^{-1} \mathrm{~K}^{-1}\right)$ at a temperature of $50^{\circ} \mathrm{C}$ which shown by the difference of within $\pm 3 \%$, comparing to the THB 500 LINSEIS test which indicates a fairly accurate of test equipment.The negative value of thermal conductivity difference means greater the testing result than literature value and vice versa. Other than that, of the five-time testing, this tool also showed good repeatability with a standard deviation of less than $3.5 \%$, this indicates that the test tool has made sufficient precision.

Uncertainty analysis also was done to predict uncertainty level for each used tool by using Kline and McClintock method [20].

Table 4. The uncertainty of thermal conductivity.

\begin{tabular}{|c|c|}
\hline Material & Thermal Conductivity $\left(\mathbf{W m}^{-\mathbf{1}} \mathbf{K}^{\mathbf{- 1}}\right)$ \\
\hline Stainless steel 304 & $15.67 \pm 1.61$ \\
\hline Commercial Bronze & $37.07 \pm 2.13$ \\
\hline
\end{tabular}

Furthermore, the apparatus was used to obtain thermal conductivity in a high-temperature condition which was conducted at a temperature of $50^{\circ} \mathrm{C}$ to $400^{\circ} \mathrm{C}$, temperature intervals of $50^{\circ} \mathrm{C}$, and included uncertainty of $\pm 9 \%$ as shown in Figure 2. The reference value of thermal conductivity of stainless steel 304 at high temperature was also obtained from other research [18] which demonstrate the thermal conductivity of stainless steel 304 alters with the temperature rises, see the continual black straight line. From the Figure 2, it is clear that in the comparative method existence of the thermal contact resistant between surfaces of samples and meter bar has significantly affected by the error [21]. The created equipment has a specification only for thin material testing and does not allow the placing of a thermocouple on the sample material, so to determine the surface temperature of the material or sample $\left(T_{H}\right.$ and $\mathrm{T}_{\mathrm{C}}$ ) only be done by calculation. Meanwhile, from other research which using the same method and allowing the thermocouple to be bored to the material sample, the thermal contact resistance does not significantly affect the calculation of $\mathrm{T}_{\mathrm{H}}$ and $\mathrm{T}_{\mathrm{C}}$ because those values were measured directly using a bored thermocouple in the sample [15]. Several methods were applied such as pressure application, liquid/gel adding, or minimize the probe for minimizing thermal contact resistance. Application of pressure decreases or minimizes thermal contact resistance, but over valued of pressure damage the specimen and cause deformation of the contact surface [21,22]. For the thin or fragile material, the pressure method is impossible. By ASTM D5470-06 [21], the pressure can be classified based on the hardness of material, for soft materials applied pressure is $0.069 \mathrm{MPa}(10 \mathrm{psi})$ while for the hard material is $3.4 \mathrm{MPa}$ (500 psi). The materials which use as validation process of apparatus were metallic bronze and stainless steel which were be classified as hard materials so that the pressure on the test was $3.4 \mathrm{MPa}$ or $46.0 \mathrm{~kg}$ with the cross-sectional area of $1.33 \times 10^{-4} \mathrm{~m}^{2}$. Then during the pressing process, application of a thermally conducting liquid or so-called thermal grease such as silicone oil to the surface was a logical way for replacing air cavities between both of surfaces. Air cavities have very low thermal conductivity even though 
on the very smooth surface $\left(0,024 \mathrm{Wm}^{-1} \mathrm{~K}^{-1}\right)$ or a high thermal contact resistance, $[2,22]$. There were two materials used as thermal grease on testing, the HC-131 for the initial validation at $50^{\circ} \mathrm{C}$ and Huskey 2000 Lubricant and Anti-Seize Paste for High Temperature.

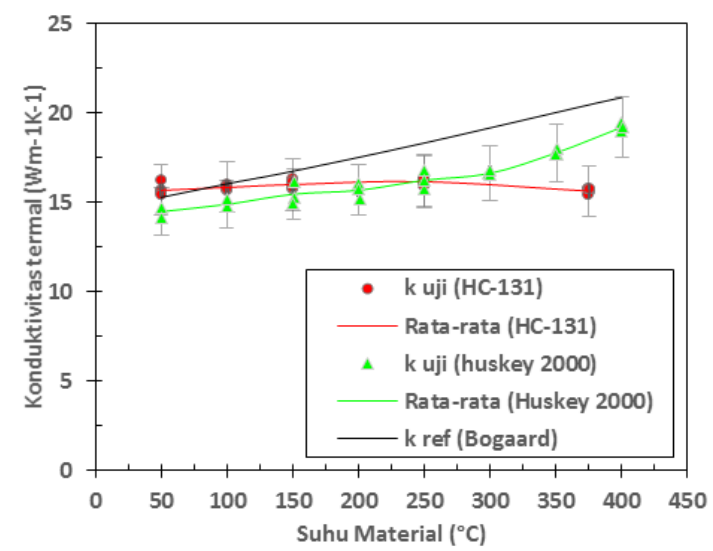

Fig. 2. Thermal conductivity of stainless steel at temperature of $50^{\circ} \mathrm{C}-400^{\circ} \mathrm{C}$

Figure 4.1 shows the result of a test using both of thermal greases at the same condition test. At a temperature of $50^{\circ} \mathrm{C}$ to $200^{\circ} \mathrm{C}$ for thermal grease of $\mathrm{HC}$ 13 , the difference of thermal conductivity of material to the literature only by $-2.55 \%$. The difference is getting up when the temperature rose from $250^{\circ} \mathrm{C}$ to $375^{\circ} \mathrm{C}$ with a maximum difference of $23.6 \%$ because $\mathrm{HC}-131$ is only capable in temperature of $-30^{\circ} \mathrm{C}$ to $150^{\circ} \mathrm{C}$. At a temperature of $200^{\circ} \mathrm{C}$ the thermal grease become dry and then air fill the cavities of contact between the sample with the meter bar. In addition to inhibiting heat transfer due to its low thermal conductivity, the air also causes corrosion of the copper used as the material meter bar. Temperatures increase corrosion on copper rapidly so that the copper surface is formed of two layers covering the copper.

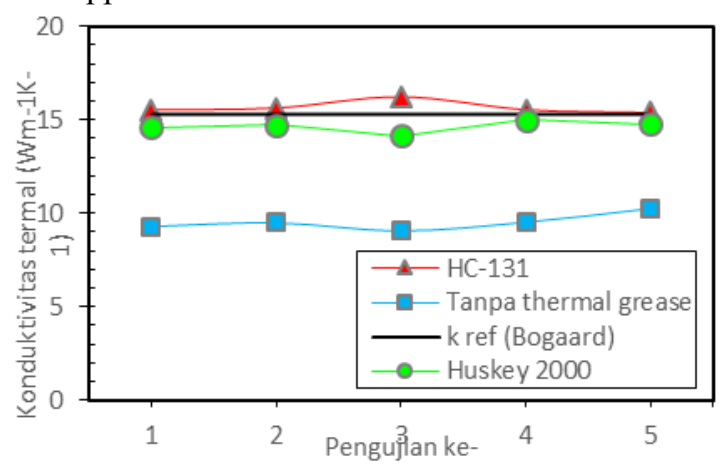

Fig. 3. Comparison of thermal conductivity of stainless steel using thermal grease HC-131, Huskey 2000 and without thermal grease at temperature of $50^{\circ} \mathrm{C}$

The inner layer of corrosion that $\mathrm{Cu}_{2} \mathrm{O}$ and the outer layer consists of $\mathrm{CuO}$ and $\mathrm{Cu}_{2} \mathrm{O}[23,24]$. This layer raises the contact resistance between the meter bar with a bigger sample, resulting in thermal conductivity test results using $\mathrm{HC}-131$ decreases when the temperature further rises.
Meanwhile for Huskey 2000, at a low temperature, the difference of $5.27 \%$ was higher than $\mathrm{HC}-131$ because the thermal conductivity of the HC-131 larger $(0.62$ Wm-1K-1) compared to Huskey in 2000 with its main function as a lubricating oil and anti-seize. However, at a high temperature of $250{ }^{\circ} \mathrm{C}$ to $400^{\circ} \mathrm{C}$, the difference is relatively constant of $7.93 \%$ because of the Huskey 2000 capable of operating up to a temperature of $1093.33^{\circ} \mathrm{C}$ $\left(2000^{\circ} \mathrm{F}\right)$. Also, the maximum temperature can be achieved higher at $400^{\circ} \mathrm{C}$ with the same heater power 858 Watt, exhibiting better thermal conductivity at high temperatures so that the maximum temperature can be accomplished higher also. However, the use Huskey 2000 showed better results compared with air or without using the thermal grease this case is shown in Figure 4.3 the results of comparative testing of the use of thermal grease HC-131, Huskey 2000 and without the use of thermal grease.

\section{Conclusions}

The thermal conductivity measurements apparatus with axial heat flow method has been manufactured based on the standard ASTM D 5470-06 and has good enough capability in measuring the material at a temperature range of $50^{\circ} \mathrm{C}$ to $400^{\circ} \mathrm{C}$. In the initial validation of the material used stainless steel and bronze by a margin of literature by $-2.55 \%$ and $2.44 \%$ and the standard deviation of the five tests of $2.09 \%$ and $3.23 \%$ demonstrated accuracy and precision tools are pretty good. As for validation at high temperatures showed good results also by a margin of $7.93 \%$ of the literature on the highest temperature of $400^{\circ} \mathrm{C}$.

\section{References}

1. Reif-Acherman, S., J. Heat and Mass Transfer 77, 542-563 (2014)

2. Cengel, Y.A., Heat \& Mass Transfer: A Practical Approach (McGraw-Hill Education (India) Pvt Limited, 2007)

3. Kurniawan, A., Pengembangan Semikonduktor Tipe-P Untuk Modul Termoelektrik Berbasis Material Zno (Universitas Sebelas Maret, 2014)

4. Xamán, J., Lira, L., and Arce, J., Applied Thermal Engineering 29, 617-623 (2008)

5. Xing, C., Jensen, C., Folsom, C., Ban, H., and Marshall, D.W., Applied Thermal Engineering 62, 850-857 (2013)

6. Alrtimi, A., Rouainia, M., and Manning, D.A.C., J. Heat and Mass Transfer 72, 630-636 (2014)

7. Yunianto, B., Pengujian Konduktivitas Termal Material Padat Silinder Untuk Kondisi Steady Satu Dimensi Menggunakan Akusisi Data (Universitas Diponegoro 2008)

8. Permana, B., Sistem Pengukuran Konduktivitas Panas Pada Logam Berbasis Mikrokontroler (Universitas Indonesia, 2009)

9. Dasgupta, T., and Umarji, A., Review of Scientific Instruments, 76 (9) (2005)

10. Komiya, A., Mashimo, H., Okajima, J., Takahashi, 
I., and Maruyama, S., The 31st Japan Symposium of Thermophysical Properties, 158-160 (2010)

11. Hadi, S., Nishitani, M., Fukunaga, T., Kurata, K., and Takamatsu, H., Proceedings of The Third International Forum on Heat Transfer, Nagasaki, 089 (2012)

12. Hadi, S., Nishitani, M., Wijayanta, A.T., Kurata, K., and Takamatsu, H., JTST 7 [4] (2012)

13. Hadi, S., Nishitani, M., Wijayanta, A.T., Takanobu Fukunaga, Kurata, K., and Takamatsu, H., J. Heat and Mass Transfer 69, 256-263 (2014)

14. ASTM E1225-99, E 1225 - 99 (1999)

15. Jensen, C., Xing, C., Folsom, C., Ban, H., and Phillips, J., J. Thermophysics 33 (2), 311-329 (2012)

16. Sweet, J.N., Roth, E.P., and Moss, M., J. Thermophysics 8 (5), 593-606 (1987)

17. Goldsmid, H.J., Introduction to Thermoelectricity (Springer Berlin Heidelberg, 2012)
18. Bogaard, R.H., Thermal Conductivity of Selected Stainless Steels, pp. 175-185 (1985)

19. Incropera, F.P., Bergman, T.L., and Lavine, A.S., Fundamentals of Heat and Mass Transfer (Wiley 2011)

20. Kline, S.J., and McClintock, F., Mechanical Engineering 75 (1), pp. 3-8 (1953)

21. M.Tritt, T., Thermal Conductivity: Theory, Properties, and Applications (Kluwer Academic / Plenum Publishers, 233 Spring Street, New York 2004)

22. Holman, J.P., Experimental Methods for Engineers (The McGraw-Hill 2012)

23. Tuck, C.D.S., Powell, C.A., and Nuttall, J., Corrosion of Copper and Its Alloys. 3, 1937-1973, (2010)

24. Wan, Y., Wang, X., Sun, H., Li, Y., Zhang, K., and Wu, Y., J. Electrochemical Science 7 (9) (2012) 